\title{
LOCAL GOVERNMENT SYSTEM IN ZIMBABWE AND ASSOCIATED CHALLENGES: SYNTHESIS AND ANTITHESIS
}

\author{
Wellington Jonga \\ House Number 11, Doro Close, Mufakose, Harare, Zimbabwe \\ Wellington.matambanadzo@gmail.com
}

\begin{abstract}
The local government system in Zimbabwe has experienced many changes and challenges during the colonial period and after independence in 1980. The Urban and Rural District Council Acts have been amended many times to initiate efficiency and effectiveness in local governance. The focus of such changes included the need to remove racial discrimination, abolish dual systems of development emphasizing white and black areas, develop democracy, good governance, decentralisation and to align local governments institutions' politics and policies in such a way that they support national strategies and visions for development. Despite many strategies or policies initiated over the years, it system the admirable local government system inherited from the colonial period has deteriorated significantly. Varied challenges have been articulated that include lack of funding, too much central government interventions in local issues, recentralisation through forcing local government officers to report to Governors, Provincial Administrators and District Administrators, violence during local elections, abuses of political power by the Minister of Local Government who 'willy nilly' or constantly has dismissed councillors, councils and mayors and so on. The study was a typical desk research. Documents from central government, local governments and books and journals were reviewed and analysed. The results indicate that political comment to achieving democracy, good governance and decentralization is needed. The description of the local government system of Zimbabwe in the new National Constitution (2013) is a positive development. Local government legislation has given too much power to the Minister of Local Government who has tended to abused it as evidenced by unilateral appointments of Commissions and firings of legal institutions. There is also need to elected literate councillors who can form policies or interpret statistical information like financial data especially during budget debates. The deterioration of a local government system cherished by many during the 1980s to the $1990 \mathrm{~s}$ is a clear testimony of the slow political, governance and democratic development processes.
\end{abstract}

Keywords: Government Systems, Zimbabwe Government, Politics, legislation

\section{INTRODUCTION}

Zimbabwe was a British colony and its local government system naturally reflects the colonial legacy. The Institute for a Democratic Alternative for Zimbabwe (IDAZIM) (2010:17) states, "Upon achieving independence in 1980, the country inherited a racially based model of governance that served the interests of white Europeans and segregated white from black Africans". Chigwata (2010:24) states that Government in Zimbabwe was primarily based on the principle of 'separate development' of races, notably whites and blacks, with the former benefiting more than the latter. To serve the purpose of 'separate development', local government was similarly divided on the basis of race. Urban Councils, in various forms, were elected by the whites, enjoyed sound autonomy, and provided reasonable services to the white community. The urban and rural councils were administered to the advantage of the white colonialists while the blacks were relegated to the status of third rate citizens and the blacks 
were confined in terms of living to what was called Tribal Trust Lands (Reserves) or Native Lands, African Councils and later changed to District Councils.

District Councils generally were impoverished, lacking adequate infrastructures like schools, health facilities and roads, lacking adequate rainfall and the land was infertile compared to farms forcibly grabbed by the colonialists. They were infested by tsetse-flies. The stay of blacks in towns and cities of Zimbabwe was considered temporary. They were accepted in urban areas for the sake of providing labour. The blacks were also registered during their stay in any urban area and this was meant to control their movements.

Chigwata (2010:24) further argues that 'local government was racist, exploitative and subservient in character. It was not only logical but also justified for the ZANU PF-led government to immediately after independence (1980) introduce reforms to correct the racially based model of governance. Mapuva (2011:7) affirms, "Ordinarily, the existence of Africans in urban areas was prohibited under colonial legislation unless they were providing cheap labour in mines and factories. This justifies the enactment of laws which required every African to possess a pass indicating their names and that of their employer where applicable.

Mutizwa-Mangiza (1992: 111) and Stewart, Klugman, and Helmsing (1994: 3-4) explicate that during the first decade of independence, successive efforts to end this dual system. In 1980 African Councils were abolished and replaced with fifty-seven (57) District Councils that were large and their councils were democratically elected. In 1988 (Government of Zimbabwe, 2004) the Rural District Act 8/1988 (Chapter 29: 13) was promulgated and it unified the District and Rural Councils into the single system of rural administration. The Ministry of Local Government in a document entitled Revitalization of Local Authorities (2004:6) argues that the major objective of the exercise was the rationalisation of local government in the rural areas. The amalgamation of the Rural and District Councils was seen as necessary to dismantle the former racially based local government system and create for the rural areas a local government system that would promote nation building through interaction across the colour line (Government of Zimbabwe, 2004). As a result of the 1988 legislative changes, Zimbabwe adopted a bipartite system of local government composed of Urban and Rural District Councils.

\section{Colonial Urban Local Government System A Brusque Survey}

Munzwa and Jonga (2010:125) allege that 1890 to 1939 was the first of colonial domination in the country colonially named Rhodesia. During this period many mining centres were set up, for example, Kadoma, Chegutu, Marondera, Chinhoyi, Gweru, Redciff, Bindura and Shamva. Urban councils originated with the establishment of Harare, previous named Salisbury in 1890. The creation of Harare saw the establishment of the Salisbury Sanitation Board by the British South African Company (BSACo) in 1892 in response to pressure from residents of the emerging town who were worried about sanitary conditions. Marumahoko and Fessha (2011:3) state, "The need for similar boards was evident in other fast-emerging towns. While the boards were confined to sanitation issues at first, they later evolved into what is the equivalent of the present day urban councils as they became responsible for service provision in general". In 1892, the major function of the boards was refuse collection. It meant that these boards had no executive power and heavily dependence on the company for funding, they were generally subservient to the BSACo.

Harare and Bulawayo became fully fledged urban councils in 1896 and the members were directly elected. Marumahoko and Fessha (2011:3) further explain that there was no change in the status of urban councils up to 1923 when the Company's administration was terminated on 
the granting of self-government to Rhodesia. Before 1923, the boards established remained subordinate to the BSACo which appointed the members. In 1930 the first Urban Councils Act was passed and was called the Municipal Act (1930), (Mapuva, 2011:6). City council status was conferred on seven urban councils, including Harare and Bulawayo, in 1967. During that period 26 town management boards and three local committees were established to provide services in the smaller towns. This, however, did not bring any significant change in terms of financial status.

Wekwete in Munzwa and Jonga (2010:126) states,

"... the country experienced the highest rate of increased housing stock due to vigorous stand development between 1965 and 1971. It is during this period that the housing for Africans was really embraced".

The foregoing discussion indicates that between 1890 and 1980 the relationship between central government and urban councils was that of centre- periphery. Munzwa and Jonga (2010) also concluded that the post-independence era, that is, 1980 to 1996 was marked by vigorous deracialisation of the systems including the urban and rural settlement systems.

In 1980 the Urban Councils' Act of 1973 was replaced by the Urban Councils' Act (Chapter 214). The Urban Councils Act (Chapter 214) was changed in 1995 and 1996 and replaced by the Urban Councils Act (Chapter 29:15). The Urban Councils Act [Chapter 29:15] provides for the determination and establishment of councils, qualification for election into council, management committees of councils, appointment of officials, powers, duties, functions, rights and obligations of councils and financial matters. In 1997 the Urban Councils' Act (Chapter 29:15) was varied and substituted by the 1997 Urban Councils' Act and again replaced by the Local Government Laws of 2008.

\section{Challenges of Decentralization In Africa}

Zimbabwe's decentralisation policies are or were meant to create government structures closer to the people, to enhance participation in decision-making and to facilitate development. When discussing decentralisation and local government system in the Constitution of Zimbabwe, Olowu (2009:4) outlined the following as challenges of decentralisation in Africa:

A. The fundamental problem of decentralised local governance in developing countries is the fear of national leaders that the transfer of power represents a zero-sum game in which local leaders (who might also be politicians in a different party) gain power and resources at their expense. This could be a real problem in view of the nature of highly personalised nature of politics especially in many African countries and the tendency for the opposition to gain in strength in the major especially capital cities.

B. A number of decentralisation programmes have simply transferred power, authority and resources from a group of elites at the national to the local levels. Such elites might be traditional or conservative and against all forms of modernity or change or they might be transformative or corrupt.

C. Weak individual (human resource) incentives put available capacities out of reach of district and community level authorities. For instance, the remuneration packages for staff at local communities are often set at levels lower than at the national government.

D. There is disconnection between the national and local levels. Such disconnection between micro and macro, upstream and downstream aspects of economy and society fosters a less effective development process even though the local level may actually experience a deeper, more focused development impact. 
Organisations function the way they are because of the institutional incentives, which exist or are missing. Organisations provide opportunities for cooperation among individuals and the organisational rules determine the response of these individuals to either cooperate or shirk. Hence, institutional incentives are those elements that make people who work in or with these organisations - as leaders, officials and clients - to display diverse behaviour modes that either support or undermine local development.

Before 2013, the Zimbabwe Constitution contains no provision on local government. One might have thought that this was a legacy of the British colonial inheritance as local government is regarded as a statutory not a constitutional issue in erstwhile British colonies.

\section{Decentralisation Policies In Zimbabwe- A Brief Survey}

Moyo (2010, Online) argues that after independence decade there has been a series of legislative enactments, directives and pronouncements which created structures and procedures facilitating the devolution of responsibilities and powers to lower levels of government. The changes were influenced by reasons such as the need to encourage efficiency and effectiveness in the delivery of goods and services, the need to facilitate development in urban areas, the need to encourage democratic good governance, and the desire to bring and promote strong leadership like the introduction of the Executive Mayoral System in 1996.

Chombo the Minister of Local Government (2009: x), explains that the legislations that defined the modus operandi of the local government sector are; Provincial Councils and Administration Act, The Urban Councils' Act, The Rural District Councils' Act and The Traditional Leaders' Act. The Acts among other issues define the mandate of local governments and in the process define the legal and functional relationships between and among the various actors in local government, that in essence are the key enablers to development, to the extent that same have to proffer safe lending to all development initiatives. The following paragraphs will elaborate on decentralization policies.

The Prime Minister's Directives on Decentralisation and Development (PMDDs) of 1984 and 1985, for example, established the position and roles of the Provincial Governor (PG). The directives were given a legal status in 1985 when it became the Provincial Councils and Administration Act (Chigwata, 2010:8). Furthermore, PGs are classified as political heads of provincial governments and provide leadership to the provinces thereof. Besides the PGs, the PMDDs also created other structures at the provincial level and these include; Provincial Councils (PC), Provincial Development Committees (PDC) and other sub-committees of the PDC. The provincial administrator (PA) also undertakes a very important role in provincial governance. Each province has a PA who is responsible for coordinating the activities of central government ministries and agencies at the provincial level to ensure coordinated development planning and implementation. The Village Development Committees (VIDCOs), Ward Development Committees (WADCOs), District Development Committees (DDCOs), Provincial Councils (PCs) and Provincial Development Committees (PDCs) and Provincial Governors (PGs) were also created as coordination and consultative structures under the PMDDs. The intergovernmental hierarchy of committees created by the PMDDs was mandated to take charge of local planning and development as a mechanism to facilitate popular participation (Chigwata, 2010:8).

Besides the establishment of PGs, The Prime Minister's Directives resulted in the amalgamation of the Rural and District Councils.This development left Zimbabwe with two systems of local government, that is, the Urban and Rural-District Councils. These are lower 
sub-national structures compared to the Provincial Councils. The Rural-District Councils are headed by a District Administrator. The Minister of Local Government IN 2003 directed urban councils to report to the Governors, Provincial and District Administrators. The introduction of DAs and PGs in the urban governance created serious conflicts that negatively impacted on the activities of urban councils.

The other major structure created by the decentralisation policy was that of the traditional leaders and these include chiefs and headmen. Their role is to allocate land and try civil and criminal cases among other duties. The Traditional Leaders Act of 2002 is the law that guides their governance activities.

The formation of the MDC changed in many ways the political environment, giving birth to political violence, murder, assassinations, destruction of properties, political instigated migrations locally and internationally and finally serious economic meltdown. The creation of new laws and the amendments to existing laws especially from the 1990's in many ways was part of a Zimbabwe African National Union-Patriotic Front (ZANU-PF) Party seditious strategy that was hatched to keep it in power. Legislative changes seemed to have too many political overtones to be paraded as democratic (Makumbe 2009:25).

The deterioration of the rule of law in Zimbabwe has definitely influenced the deterioration of public institutions like urban councils whose duty is to provide public goods and services to communities in a democratic manner. In the urban areas democratically elected councils and executives during the time of the National Unity Government were being harassed and dismissed by the central government through the Ministry of Local Government, Public Works and National Housing and some of the dismissed were mayors Mudzuri (Harare, 2004), Lionel De Necker (Gwanda 2012), Ivory Matanhire (Bindura 2011), Itai Masaka (Deputy Mayor Mutare 2010) and Brian James (Mutare 2012). All these mayors were replaced with proZANU-PF Party individuals (Sibanda, 2012:1). Councillors in a majority of these urban councils were also dismissed and replaced with what is called special interest councillors who are also ZANU-PF Party supporters. It is a common saying in Zimbabwe that democracy is now in the intensive care'.

\section{RESEARCH METHODOLOGY}

The researcher adopted a desk research methodology since adequate documented information that needed synthesis was available. Documents from the Ministry of Local Government, Urban Councils and Rural District Councils were consulted and analysed. In addition books and articles published in newspapers and journals were also reviewed. The reviewed data was organized into groups, sifted and interpreted into meaningful information. Documents relating to the historical development Zimbabwean local government system, policy issues, plans and directives were some of the major sources of data.

\section{Positives About The Local Government System In Zimbabwe}

Despite the aspect of discrimination between whites and blacks, at independence in 1980 Zimbabwe inherited a local government system that was decentralised and specifically devolved. Three types of local governments were created and they included Urban, Rural and District Councils. The Prime Minister's Directive of 1984 redefined the types of local governments and reduced them to only two, that is, the Urban Councils and the Rural District Councils.

The Prime Minister's Directive was a policy pronouncement that was meant to realign local government activities to be supplementary and complimenting national government 
development efforts and further refocused local governments on development in their areas of jurisdictions. Also a possible correct perception is that a pseudo one party system pursued by a pro-socialist ideology Zimbabwe African National Union- Patriotic Front (ZANU PF) expected this party to keep constant and clear contact with the grassroots where its power or support base was anchored. The policy also reduced discriminatory tendencies of the earlier tripartite arrangement that gave more advantages to urban areas and farming areas that were inhabited by whites.

The local governments enhanced governance through providing democratic platforms at local levels were issues of a local nature are debated and policy decisions and development plans or options are voluntary agreed. Thus local governments in Zimbabwe are both political institutions that develop local development policies and further support development policies initiated and are being implemented by central government. They are organs of state power. Local politicians are basically inducted into politics before becoming national policy makers. The politicians and other stakeholders meet and discuss issues of a local a nature directly. In Zimbabwe, the local governments provide platforms through which direct democracy can be realised.

Zimbabwe Women's Resource Centre and Network (ZWRCN) (2010:4and8) argues that government policies and reforms on legislation are at times delivered through fiscal pronouncements. In the financial area decentralisation policy in Zimbabwe promoted participatory budgeting system. Central government realised that the residents were crucial stakeholders in the governance of urban council and therefore were supposed to be empowered by participating in budgeting. Participatory budgeting is part of overall strategic effort to promote local and engendered democracy and smart partnerships in local authorities. The main objectives of participatory budgeting are to promote civic intervention and participation in local governance, involve the communities in generating self-sustaining livelihoods options, and promote accountability and transparency in local public finance and budgeting (ZWRCN, 2010:8).

The stakeholders are critical in determining the democratic and governance space of local governments. ZWRCN (2010:8) in an attempt to explain decentralisation policy quotes the Ministry of Local Government, Urban and Rural Development Circular Number 6 of 1983 that states: "Council should consult with residents and stakeholders whenever it proposes new rents, services and supplementary charges in any given council." Participatory budgeting is being practised in Zimbabwe urban councils since the year 2000. However, as a matter of policy all local governments are expected to submit certificates of consultation to central government through the Ministry of Local government (ZWRCN, 2010:8). The Urban Councils' Act requires the same. However, no records are available in the urban councils to prove that such meetings are taking place.

Local governments have specific boundaries and their functions are clearly spelt out in the Urban Councils and Rural District Councils Acts. This scenario allows their stakeholders to keep a typical control over the bureaucrats (employees) who provide special services or advise to politicians. Thus in Zimbabwe, the principles of good governance guides and is the focus of such institutions. Important principles of good governance pursued by local governments are transparency, accountability, rule of law, responsibility, and participatory decision-making. The compact nature of a local community could allow some of the mentioned principles to be greatly achieved compared to what could be achieved by the national government. 
Critical local services provided to the advantage of the local communities include sewerage treatment, garbage collection, roads, drainage and health facilities development, provision of electricity, housing, social amenities, schools, land development, control of livestock, provision of land to citizens, solving conflicts, providing justice especially through chiefs and headmen, controlling deforestation and so on.

\section{Challenges Confronting Local Governments In Zimbabwe}

The new Zimbabwe Constitution of 2013 unlike the previous one has defined the local government system in Zimbabwe in great detail. It was unforgiveable that the previous Constitution deliberately did not explain the local governance giving the Minister of Local Government advantage of creating the Urban Councils Act and allowing him to amend it as he wish. This scenario led the said Minister to be too powerful and inevitably abusive to local governments to benefit ZANU PF Party. Zimbabwe Institute (2005:15) states, "Local government in Zimbabwe, unlike in other modern democratic states, has no constitutional backing. The constitution of Zimbabwe is silent on the establishment of local government save for Section 111 of the Constitution of Zimbabwe that recognises the existence of Provincial Governors and Chiefs as sub-national levels of government. Yet, the Zimbabwe Constitution, in its preamble, states that the "constitution is the supreme law of Zimbabwe and if any other law is inconsistent with this constitution that other law shall, to the extent of the inconsistency, be void". Zimbabwean constitutional law thus regards the Constitution as being supreme and superior even to the Legislature. In that regard, the administrative and political culture in Zimbabwe highly regards those matters enshrined in the Constitution, which cannot be changed before careful review, consultation and defensible justification". Zimbabwe Institute (2005:16) further states that the Constitution should; establish local authorities as a free standing level of government at sub-national level, specifically the district and provincial levels for Metropolitan Provinces; spell out the various responsibilities and functions of the different levels of governments, state the major objects and responsibilities of local governments and that it should state the revenue sharing. Therefore, if the Constitution establishes the local authorities, central government will have no automatic right to suspend and dismiss local authorities and its elected representatives. Making local government a constitutional creation will also do away with the restrictive ultra vires doctrine.

\section{Voting System}

Before 1980 the Black majority in Zimbabwe were not allowed to vote. Their stay in Urban Areas was only temporary. Kamete (200b:6) asserts that what buttressed the race card was a host of legislative and administrative instruments, chief among which was the constitution. Kamete (200b:6) points out that the Land Tenure Act designated urban areas as "white only" areas, blacks being allowed only to provide labour there with the understanding that they would retire "home" when their usefulness run out. Kamete (200b:6) in addition, indicates that the blacks being aliens in the urban areas could not own property there. Consequently, they could not vote in urban local government elections. These racist laws were reinforced by the promulgation of many similar laws, for example, the Land Apportionment Act which took away land from the blacks in the rural areas.

Machingauta (2009:11) contends that there was no place for Africans in the local government system that was developing until the 1950s when the African Advisory Boards were set up to look after the interests of the growing African population in the towns. At independence attempts were made to bring all urban areas together and for the first time Africans could participate in local government elections by electing councillors for their own areas. Until the1990s very few blacks owned property in Harare and ZANU-PF Party did not quickly change legislation after independence in 1980 because residents who did not own property 
were not trusted voters and because politicians felt they could be swayed any direction. Kamete (2000b:9) argues that by 1990, Harare had about 100000 people on the housing waiting list. This indicates that the majority were lodgers and that the politics and administrative issues in urban areas continued to be dominated by whites living in middleincome and low-density areas because they owned property.

By 1990 those living in the high density areas were 400000 and in the low density areas less than 122 000. Thus Kamete (2000b:9) argues that those not voting in the low income areas were about 75\%. Ten years later this number increased to $80 \%$. Kamete (2000b:9) emphasised that what made the local vote undemocratic was the fact that the affluent groups who could vote were decidedly in the minority. Currently voter apathy is rampant in urban areas and still a minority of blacks currently own property.

Kamete (2000b:11) further alleges that by the year 2002 ZANU-PF Party officials owed the City of Harare about Z $\$ 330$ million (US $\$ 7.3$ million) in unsettled bills. Therefore in democratising local government elections the politicians felt that control of local resources by the wrong people was retarding their progress and access to coveted resources. The only way to change the situation was to overwhelm the system with popular vote. The point is legislative amendments between 1980 and 2000 could have been driven by the desire to loot and gain power rather than to benefit the majority poor. In 2002 residents who were not Zimbabweans by descent and/or had dual citizenship were disenfranchised. The aspect became topical in the crafting of the new constitution because ZANU PF Party wanted to disfranchise all those taken to be rebels who supported the Movement for Democratic Change Party. Kamete (2000b:16) claims that legislation disadvantaged a quarter of a million of registered voters. In rural areas violence, intimidation, beatings and murder are used by rogue politicians to get votes and therefore freedom, rule of law, responsibility and accountability is greatly limited. Democratic local governance is thus a wish that may take years to achieve if attitudes to who is the enemy does not change.

\section{Poor Service Delivery}

Madzivanyika (2011:14) maintains: "Basic services must, be available, accessible, culturally acceptable, and affordable, of good quality and provided on a non-discriminatory basis." Zimbabwe Election Support Network (ZESN) (2008:1) also explains that residents in the various local authorities in Zimbabwe have had to contend with a plethora of problems which include uncollected refuse, bursting sewers, erratic water supplies, roads filled with potholes which have become a nightmare for motorists. The Network further states that there has been a general dissatisfaction among residents with the level of service delivery and these are some of the considerations that might have affected the choices of the electorate as they chose the councillors for their respective local authorities.

Madzivanyika (2011:34) states that the Urban Councils' (UC) Act provides electricity as a competence of UCs. The generation and distribution of electricity was revoked in 1989 from UCs by central government and the authority to do so was given to the Zimbabwe Electricity Supply Authority. Madzivanyika argues that this removed a potential revenue generating base from UCs. Lack of constitutional protection weakens the ownership of functions they perform. The system is also wasteful and in some instances causes over concentration of resources on one service at the expense of other basic services.

The situation in Chitungwiza provides a summary of the deteriorating situation of the urban areas in Zimbabwe. The Herald, 22 November (2005:1) expressed that a visit to the workshop 
yard by the Minister of Local Government, Public Works and Urban Development and Chitungwiza Council officials revealed that 15 trucks, and 11 tractors plus several service vehicles were grounded. The paper (ibid) further states that garbage in some areas is not collected for long periods and have become an eye sore and a health hazard. The Newspaper gives an example of roads in (low density suburbs) Unit N, L, P, St. Mary's and parts of Zengeza that were blocked by garbage. Burst sewer pipes and water shortages compounded the horror. It also indicates that infant deaths were recorded in the town as a result of the unhygienic conditions and in addition at least 2000 cases of watery diarrhoea cases were also reported at health centres in 2005.

Despite the Minister's threats to force urban councils to deliver, the City of Harare has no resources. The Town Clerk argues that they have failed dismally and was now appealing to the government to bail out. More than US $\$ 250$ million was needed to rehabilitate the city's water treatment works and delivery infrastructure but the Council has no alternative means to raise such big amounts of money. It is absurd that for political mileage the ZANU PF Party during national elections campaign has promised to cancel debts owed by residences for services provided. Currently local governments are cancelling big figures of money they were owed by their customers. It has exacerbated their financial position.

The Voice of America (September 28, 2012:1) claims that Zimbabwe was gripped with fears of another cholera outbreak in Harare where suburbs including Hatcliffe, Budiriro, Mount Pleasant, Tafara, Mabvuku, and Chizhanje have gone for weeks without clean water. A similar outbreak killed many residents in 2011. In the same media (September 28, 2012:1), UNICEF Country Representative Peter Salama indicated that about 4,000 Zimbabwean children die of diarrhea each year. Mason (2009:1) explains that the first large outbreak of cholera was reported in 1992 in Manicaland and Mabvuku/Tafara suburbs on the Eastern edge of Harare. About 2000 cases and a mortality of $5 \%$ were reported. The following year (1993) there was 5,385 cases and $381(6 \%)$ deaths. The next outbreak in 1998 had more than 1000 cases and 44 deaths. In 1999 cases reported were 5,637 and 385 deaths. Most of these cases were in Chipinge and Chiredzi, in the South-East of the country again close to the Mozambique border. During 2002, the cases that were reported in Manicaland and Mashonaland East totaled 3125 including 192 fatalities. At least 304 cases with 11 deaths were reported in Kariba, on the border with Zambia in October 2003 and a further 99 cases, 16 of them fatal, were reported from Binga, a small fishing community on the shore of Lake Kariba. Mason (2009:1) also claims that a severe outbreak of cholera has been reported in Zimbabwe since mid 2008. At least 92000 cases and over 4000 deaths were registered in 2008.

The researcher has included the above statistics to demonstrate the impact of failures of the urban councils to provide effectively and efficiently the critical services to the urban communities. Thus the failure to supply clean water and to maintain sewerage system drainage is the major culprit in the outbreak of cholera, diarrhoea and typhoid.

\section{Undemocratic Legislative Amendments}

Zimbabwe United Residents Association \& Combined Harare Residents Association (2003:5) claim that the Urban Councils Act of 1995 is characterised by delegation rather than devolution of power and functions. The Act is built upon the concept of upward accountability and not local accountability. The Minister responsible for local government has a say in many issues and not the local people or civic groups. Related to the above, Central Government, and not the local people, retains firm control over all local authorities with powers to suspend the enabling legislation, suspend a local authority and put in an administrator as has been done in the case of City of Harare, and suspend individual councillors and prohibit them from taking active part 
in local politics. Chatiza (2010:39) asserts that the legal provisions for people's participation in governance generally, and local government affairs in particular, are weak in Zimbabwe because there is no consultation during decision making on critical issues.

\section{Central Government Usurping Local Power}

Madzivanyika (2011:33) alleges that efficient and effective provision of services is undermined by a high level of central interference in the decisions of local governments. In 2005, the Minister of Local Government issued a directive which revoked water management functions from UCs and transferred its management to the Zimbabwe National Water Authority (ZINWA). Madzivanyika (2011:34) contends that the transfer of water to ZINWA without the necessary accountability mechanisms led to regressed patterns in the provision of water and sanitation in urban areas. The transfer of the UCs function to provide water also deprived UCs of local taxing sources of revenue thereby constraining their already weak revenue bases. ZINWA failed to perform efficiently and effectively in the new task allocated to it and Madzivanyika (ibid) explains that eventually because of the poor performance, in 2008, the minister responsible for water provision issued another directive handing water provision back to councils. The announcement of such directives only indicates the nature of volatility in the operations of urban councils despite many alterations to the Urban Councils Act. The researcher also views such changes as retarding good planning and development of urban water provision policies and strategies. It indicates lack of vision on the part of leadership. They are using management based on opportunism tactics.

The Financial Gazette, (February, 27 - March5 2003:4) published a story on the conflict of the Minister of Local Government and the mayors over the introduction of District Administrators (DAs) in urban areas. The mayors felt it was a strategy by government to want to interfere with their operations and to force them also to report to ZANU (PF) appointed functionaries. The Minister's directive was declared outside the provisions of the Urban Councils Act. The Financial Gazette, (February 27 - March5, 2003:4) writes further that the move from the Minister were part of a wide and wicked manoeuvre to dampen spirits and frustrate the executive mayors by making them report to bureaucrats sympathetic to ZANU PF. Madhuku argues in the Financial Gazette, (February 27 - March5, 2003:4) that the government wants to scuttle the wishes of the electorate by allowing ZANU PF to come through the back-door. He also feels that the approach whereby mayors report to Governors and District Administrators was a death knell for democracy because the move simply makes elected officials accountable to hand-picked ZANU PF functionaries. The Manica Post, (6-12 January, 2006:9) reveals a situation where the mayor and councillors of Mutare resigned because of too much intervention by the Minister of Local government in the affairs of the city council. A Movement for Democratic Change (MDC) provincial secretary for information and publicity in the same Newspaper explains that the resignation decision by MDC Party councillors and mayors was taken after realising that the elected councillors and mayor couldn't work under the newly appointed commissioners.

The Commissioners are appointed by the Minister of Local Government in situations where he/she has dismissed or dissolved a council. The problem arose because the Commissioners were handpicked by the Minister and the major qualification was there links to ZANU-PF Party.

\section{Perceptions On The Appointed Commissions For Councils}

Kamete (200b:14) explains that poor urban governance led people residing in high density areas to revolt and caused the Ministry of Local Government to dissolve council and dismiss all councillors of the City of Harare in 1999. Despite the fact that the law gives a Commission a 
limited lifetime of only six months, the Harare City Commission lived beyond its time and appeals to the High and Supreme Courts were in vein. This tactic of dismissal of councils and appointments of Commissions was repeated in other towns. Kamete (2000b:14) maintains that ZANU-PF Government could not call elections because it was losing support in urban areas as exemplified by the situation in Bulawayo, Masvingo and Chegutu were the opposition had won. A challenge is that culture or perception of regarding anyone who defeats a ZANU PF Party candidate in elections as an enemy is common or rampant though wrong for democracy to develop. People who compete are not enemies but friends in good faith.

The dissolution of councils and also dismissal of councillors who were substituted by Commissions is a common phenomenon in Zimbabwe urban councils' governance. ZESN (2008:2) states that the operations of local authorities were paralyzed because no tangible cause has been provided and the dismissal of councillors and replacing them with Commissions was prevalent in most areas where MDC had won elections, for example, Harare, Mutare, Chegutu and Kariba. Jonga (2012:339) argues that even commissioners are persons who are not experts in the administration of local governments/urban councils. The Urban Councils Act is again silent on the basic requirements needed if a person has to be appointed a commissioner. The lack of necessary expertise or knowledge results in councillors or such commissioners rubber- stamping issues raised by employees. Where councillors have been fired for poor service provision, mismanagement of councils' assets, funds and so on, for example, in Harare and Mutare cities, the commissions appointed have done no better. There are signs of further deterioration of infrastructure and services in such cities.

\section{The Issue Of Making Local Laws}

Different urban councils are expected to create by-laws suitable in governing areas of their jurisdiction. The power of making by-laws however, has been usurped by central government through the Ministry of Local Government. Madzivanyika (2011:34) laments that the making of by-laws is another area where local authorities have been frustrated by central government. Local Government Laws 2008 state that the Minister of Local Government has power to approve small laws that are made by councils (Marumahoko, 2010:47). It seems, in Zimbabwe the law gives the Minister the discretion either to approve or disapprove the by-laws. The discretion given to the Minister potentially compromises the functions of UCs, because by-laws can only take effect after approval by him/her. The Minister has been given excessive control powers over the activities of local governments. The way the powers are applied hates good governance in Zimbabwe. Madzivanyika (2011:35) further claims that a thriving Urban Local Government (ULG) requires citizens to set the overall agenda on service provision. The design of the UC's Act compromises also the efficiency of UCs in the event that the Minister fails to approve timeously or he disapproves the by-law.

\section{Financial challenges}

Lack of revenues or failure to expand the revenues base will compromise the final incomes of the councils. Limited revenues will inevitably results in inadequate services and in addition ineffective and inefficient responses to public demands or needed investments. In Zimbabwe, councils cannot change laws impacting on revenue generation, for example, taxes and surcharges without the approval of the Minister of Local Government. Madzivanyika (2011: 35) explains: "The design of the UC Act limits the capacity of UCs to raise taxes or tariffs. UCs can only raise, for example, property taxes, surcharges or borrow within limits set by the minister."

The Manica Post, (3-9 February, 2006:1) quotes Chombo defending the increase of services rates by most local authorities, "It is important for them to charge economical rates for them to 
remain viable. Most local authorities were struggling to make ends meet because of the rates they were charging." Maromahoko (2010: 47) portrays the deteriorating governance in urban areas of Zimbabwe by providing statistics on revenue generation in the City of Harare. He illustrated that the City of Harare budgeted to collect revenue to the tune of US\$230.09 million in 2010 against an expenditure target of US\$275.63 million, resulting in a budget deficit of US $\$ 47.54$ million. In addition, the City also had a budget of US\$77.33 million revenue from water against a total budget of US $\$ 230.09$ million. The amount targeted was unacceptably low. The intrusive nature of the Ministry of local government is vivid in the expenditure activities of urban councils. Marumahoko (2010:48) maintains that Section 309 of the 1996 Urban Council Act (and also the Local Government Laws 2008) requires all urban councils to supply the Minister of Local Government with any record he may solicit to discharge his duties.

Governance woes were exacerbated by the failure of government departments to pay for services offered to them by urban local governments. Documentary evidence indicates that every year each ministry is allocated funds by Treasury for the payment of services and supplementary charges especially those ministries that had offices and institutions at provincial and district level. Ministries were not paying bills to local authorities for provision of services like refuse removal, water, and sewage facilities. Most sector ministries still viewed their debts to local authorities as being ex-gratia and not obligatory. The ministries thus are depriving local governments of important revenues that are vital in financing service provision in other areas. Strict rules and regulations need to be put in place to force the concerned ministries to take necessary steps to pay the huge amounts of revenues they owe the urban councils.

\section{Metropolitan Governors Meddling In Urban Councils' Activities}

The Urban Councils' Acts do not command the personnel of such institutions to report to the Governor's office. In 2000 the then ruling party ZANU-PF noticed that it was losing ground to the opposition party, the MDC that it surreptitiously developed a decision to co-opt District Administrators and Governors in the governance of urban councils. The Zimbabwe Institute (2005:18) argues that the confusion and complication arises from the unclear and unspecified division of labour between the Executive Mayor and the Provincial Governor, the former representing and speaking for the electorate, the latter representing the President and speaking for him. The Institute further argues that the problem is clearly exacerbated in situations where the Executive Mayor and the Governor belong to two different parties subscribing to different philosophies and approaches towards urban governance.

\section{Constant Changes To Mayoral Systems}

Zimunya (2004:2) argues that from 1980 to 1995 municipalities and cities in Zimbabwe were run under the ceremonial mayoral system. Under this system, all councillors were elected on ward basis. There were no special qualifications for a councillor except age and eligibility to vote. There were no qualifications required for a mayor despite the fact that he/she would assume some administrative responsibilities. The Urban Councils' Act of 1997 [Chapter 29:15] was prominent because it introduced the executive mayors in municipalities and cities. The executive mayors were directly elected by the residents and held office for four years. Their qualifications were known. Zimunya (2004:3) explicate that Section 49 (1) of the Urban Councils Act set out the educational qualification of the executive mayor which are as follows: (i) a general certificate of education with passes in at least five subjects including , at Ordinary Level; and (ii) either (A) a general certificate of education with passes in at least two subjects at Advanced Level; or (B) a post Ordinary Level qualification in any career or profession obtained after pursuing at least two years of studies. 
Zimunya (2004:3) states that executive mayoral system was generally borne out of a direct perception by central government of weaknesses in the decision-making process of councils in the ceremonial mayoral systems. The absence of a full time political leader in council who would guide and direct both elected and appointed officials in the administration of the urban council encouraged the changes. Zimbabwe Election Support Network (ZESN) (2008:2) claims that the abolition of the Executive Mayor was more for political expediency than economic rationality because by the year 2000, most urban local authorities such as Kariba, Chinhoyi, Mutare, Chegutu and Bulawayo just to mention a few, had been under the management of MDC Party.

In the State of Local Government in the Country (2004:100), the Ministry of Local Government argues that the view of ZANU-PF Government and shared by many is that the institution of the executive mayor has become unsustainable in terms of the resources because of the expensive on mayoral mansions and Mercedes Benz and the exit packages are many. luxurious life style of the executive mayor is happening at the expense of service deliver.

\section{Minister of Local Government, Public Works and National Housing directives}

Kamete (200b:15) asserts that the minister issued three serious directives that crippled the authority of councils and mayors. The first directive called all recruitments and promotions effected by the Commissions in the previous six months from June of 2000. The second directive instructed council to refer to the Minister all council resolutions dealing with human resources and financial matters. The third directive banned all mayors from attending Cabinet Action Committee meetings. The directives were an attempt to clip the wings of the new city administrations which were viewed by ZANU-PF politicians and Ministers negatively because they were appeared to be focused at outperforming previous administrations. The previous administrations were dominated and led by ZANU-PF Party officers and therefore the new scenario if it was supported was going to be an embarrassment to then ruling party.

\section{Issues Of Good Governance}

In the urban areas of Zimbabwe conflicts and administrative difficulties are aggravated by many situations. Many councillors are illiterate or semi-literate to the extent that they depend on the employees to function in councils' duties. Some employees have worked for many years in a council so that they find it impossible to be supervised by a junior councillor. Major difficulties appear were an employee is a senior politician of a party from which a councillor is elected. The councillors find it difficult to supervise their party superiors. Sachikonye, Chawatama, Mangongera, Musekiwa and Ndoro (2007:54) state that in the urban councils of Zimbabwe staff appointments are made along partisan lines and the backers among the legislators are obliged to 'protect their employees' in council, making accountability of such officials to their superiors, citizens and council as a whole a nightmare. Sachikonye, at al. (2007:54) further argue that where the officials are well qualified and competent, they tend to intimidate and challenge the elected and in some cases, the elected are made to account to the appointed.

\section{Professional And Academic Qualifications Held By Councillors}

In a study conducted by Jonga (2011:7 ), the researcher asked respondents the qualifications they held at joining councils. The findings revealed that $46.1 \%$ of the councillors and informants and $91.3 \%$ of the employees had $0^{\prime}$ levels and A' levels. Table 1 below shows the distribution of the responses. 
Table 1: Qualifications held at joining council ( $\mathrm{N}=34)$

\begin{tabular}{|c|c|c|c|}
\hline \multirow[b]{3}{*}{ Designation } & \multicolumn{3}{|c|}{ Frequency } \\
\hline & \multicolumn{3}{|c|}{ ‘0’ Levels } \\
\hline & Yes & No & $\begin{array}{l}\text { No } \\
\text { Response }\end{array}$ \\
\hline Councillor & 4 & 4 & 2 \\
\hline \multirow[t]{2}{*}{ Employee } & 14 & 0 & 10 \\
\hline & \multicolumn{3}{|c|}{ 'A' Levels } \\
\hline Councillor & 2 & 3 & 5 \\
\hline \multirow[t]{2}{*}{ Employee } & 7 & 4 & 13 \\
\hline & \multicolumn{3}{|c|}{ Certificate of competence } \\
\hline Councillor & 3 & 2 & 5 \\
\hline \multirow{2}{*}{ Employee } & 9 & 2 & 13 \\
\hline & \multicolumn{3}{|c|}{ Diploma } \\
\hline Councillor & 4 & 4 & 2 \\
\hline \multirow[t]{2}{*}{ Employee } & 10 & 3 & 11 \\
\hline & \multicolumn{3}{|c|}{ First Degree } \\
\hline Councillor & 0 & 10 & 0 \\
\hline \multirow[t]{2}{*}{ Employee } & 12 & 4 & 8 \\
\hline & \multicolumn{3}{|c|}{ Masters } \\
\hline Councillor & 0 & 10 & 0 \\
\hline \multirow[t]{2}{*}{ Employee } & 6 & 4 & 14 \\
\hline & \multicolumn{3}{|c|}{ Doctorate } \\
\hline Councillor & 0 & 10 & 0 \\
\hline Employee & 2 & 4 & 18 \\
\hline
\end{tabular}

"The data in Table 1 shows that 12 employees (52.2\%) had first degrees, followed by (10) $47.8 \%$ who had diplomas and (9) 39.1\% who had certificates. In addition two (8.1\%) of the respondents indicated that they had doctorates. Further investigation revealed that those who indicated that they had doctorates could have been holders of Medical degrees than Doctor of Philosophy degrees. This research discovered that highly qualified graduates are a rare species in urban councils because of poor working conditions and especially political interference from central government through the Ministry of Local Government. The findings also revealed that every employee had a qualification of some kind at joining council and many of the councillors did not have professional qualifications even 0' levels. Councillors are elected on party terms (politics) and qualifications do not feature much when choosing candidates for election." No academic or professional qualifications are required for anyone to be elected councillor. However, the Urban Councils Act chapter 29:15 (1996:534) (Part V) Section 40 (Qualifications for election as Councillors) states:

Any person who -

(a) is a citizen of Zimbabwe; and

(b) has attained the age of thirty years; and

(c) is entitled in terms of section seventy to vote at an election of councillors; and is not disqualified from nomination or election as a councillor in terms of section forty-one.

-shall be qualified to be elected as a councillor. 
"An informant explained that a councillor is a helper to citizens/residents. He added that the councillor's role is not to make political noise only or to interfere with employees' work. Councillors should be professionals who are concerned mainly with the day-to-day business of councils. All those interviewed were of the opinion that the councillors need to produce curriculum vitae for the public verification before they can be voted into office. This will be some form of vetting based on their political and professional achievements, capabilities/competences and future plans for that particular constituency. The qualifications help council to place individuals into appropriate committees. Random placements of councillors into different committees are meaningless and retard their effectiveness in conducting council business." (Jonga, 2012:338)

\section{DATA ANALYSIS - RESULTS}

Makumbe (2009:26) argues that authoritarianism is visible in Zimbabwe. This perception covers national and local institutions. This refers to limited public participation in decisionmaking, lack of transparency, accountability, observance of rule of law and violations of human rights in the governance systems, and claims that authoritarianism relates to a form of arbitrary government which uses coercive instruments of the state to expedite its own purposes of monopolising power while denying political rights and opportunities to other groups to compete for that power. The interventions on the Minister of Local Government in local affairs and through many strategies are enough testimony to it.

The politicisation of public administrative institutions has meant further isolation of the opposition and its supporters. Thus the administrative institutions instead of providing public goods and services efficiently and effectively, they have been turned into agents of oppression, suppression and instruments through which institutionalised violence in perpetrated. The Institute for Democratic Alternative for Zimbabwe (IDAZIM) provides a clear example of this scenario. IDAZIM (201:4) explains that by 2008 the Movement for Democratic Change Party (MDC) was in control of all the urban councils and it was also controlling more than half of the Rural District Councils. The IDAZIM maintains that the MDC electoral strength, especially in major cities revolutionized the political scene. This is because the ruling party controls the Ministry of Local Government and levers of the power at the national level, while the opposition controls most of the local authorities. This arrangement has created political conflicts that have led some of the MDC Party mayors to be removed from their positions even if the Ministry of Local Government claim to be acting impartially and taking such measures to promote efficiency and effective administrations in urban areas. IDAZIM (2010:16) states, "In a centralised system in which the Ministry of Local Government - the "mother" ministry of all local authorities - has a wealth of legal tools at its disposal to become involved, if not interfere, in local decision-making, animosity proved inevitable." Makumbe (2009:2) states that any force or group of citizens that attempts to demand their democratic and constitutional rights are swiftly dealt with by these personalised "state" institutions in the name of preserving peace, law and order, when in an actual fact these institutions have been reduced to mere survival instruments for dictators. The state institutions here include, the army intelligence agents, police, informal youth groups and other related interest and pressure groups. They no longer serve the interests of either the state or the citizens. Instead, they are now both personalised and privatised for the benefit of Mugabe, ZANU-PF mayors and illegal informal groups that are terrorising communities in many high density residential areas (Makumbe, 2009:2).

The philosophy of creating and maintaining a country ruled ZANU-PF Party has led to serious political violence that has led to the dismissal of legitimate mayors, councillors and councils. Combined Harare Residents Association (CHRA) in The Zimbabwean Newspaper (2012:1) 
mentions that since 2003, despite the fact that people expressed their will during polls, the minister has on a number of countless times, dismissed or suspended elected councillors. The approach has earned him a pseudo title; 'the Executive Mayor of Zimbabwe'. The Newspaper in addition, argues that the Urban Councils Act has failed to put in place checks and balances on the power exercised by the centre hence; decentralisation has failed to earn its objectives with the bottom operating at the mercy of the centre. Mayors, councillors and councils have constantly been dismissed. The replacement of legitimate institutions by illegitimate ones is obviously a violation of the citizens' rights like the right to elect their leaders, rule of law, transparency and even ability to participate in decision making.

The Zimbabwe Institute (2005:31) also claims: that there are serious shortcomings in the form and implementation of the current local government policy in Zimbabwe. There is so much inconsistence between the policy and actual practice. The Institute concluded that there is need to generate a local government policy for 'all seasons'. The local government policy for all seasons should be immune to political whims of those in power. The alternative system of local government should have local government enshrined in the constitution in order to guarantee its sustenance. The 2013 National Constitution has incorporated sections describing the local government system in Zimbabwe. It should be noted however that written policies and plans need political commitment and resources to be transformed into programmes and projects. The projects are instruments for development and indicated implementation of political opinions. Local authorities should be established as a free standing and fairly autonomous level of government. The system would have decentralised structures that allow for community participation in all decisions that affect them (Zimbabwe Institute, 2005:31).

Mapuva (2011:12) argues that in Zimbabwe, the liberation background of the country which forced it to adopt a socialist/communist stance, tend to view non-state actors and the opposition parties and their supporters as saboteurs or enemies who should be guarded against or even avoided at all costs. Consequently local governance in Zimbabwe is heavily politicised with the ruling political party calling the shots to municipal authorities.

Makumbe (2009: 9) argues that when ZANU-PF Party and Government was confronted by a very strong opposition than before and since 1980 in the form of the MDC Party, the ZANU-PF regime crafted draconian laws that transformed Zimbabwe into a fascist state. However, the majority in Zimbabwe today are increasingly becoming disillusioned because they do not see their vote making any positive difference to their lives. The dismissals of councillors, mayors and councils and the introduction of Governors, Provincial Administrators and District Administrators in urban councils' administration all have failed to improve local governance. In contrast local governance has further deteriorated because of lack of vision, leadership, financial resources, corruption and lack of stakeholder and political commitment.

Mapuva (2010:18) quoting Makumbe (1998:87) argues that the cause behind the formation of residents associations in urban areas of Zimbabwe and much of the civil society movement has been frustrated and worsened by the ZANU PF government's pessimistic view that residents' associations or generally organized civil society are a fora for opposing national government policies. Mapuva claims that the suspicion of government has resulted in persecutions and surveillance of many citizens by the security agents. It is an observation that in a democracy, the authority of the government derives solely from the consent of the governed. The fundamental rationale for translating that consent into governmental authority is the holding of free and fair elections. Zimbabwe has a defacto one party system. Governance calls for the involvement or collaboration of civil society organizations in the policy formulations, planning 
and implementation of programmes and projects that impact on the lives of local communities. The Zimbabwe Institute (2005:5) expresses dissatisfaction with democratic governance in urban councils of Zimbabwe when it points out that the main legal instruments of local government invested in the President and the Minister of Local Government the power to suspend or act in place of a local authority and the power to nullify some decisions of local authorities. To show the excessive power given to the Minister of Local Government, the Institute refers readers to Rural District Councils' Act in which there are more than 250 instances where the Minister can intervene in the day to day running of Rural District Councils. The Zimbabwe Institute (2005:5) concluded that there is simply too much of the "Minister shall" concept in Zimbabwean local government legislations and this has entrenched excessive central executive intervention.

Mapuva (2011:9) argues that although Zimbabwe may be credited with a high literacy rate, it appears that these mechanisms are not as widely used as initially envisaged or as it may appear on paper. Considerations should be put to the fact that many citizens are more concerned with immediate bread-and-butter issues and in most cases do not spare time to politicking. Additionally, the current Constitution of Zimbabwe which has been in use for almost three decades does not make detailed provisions for local government and the only enabling legislation, the Urban Councils Act advocates for consultation rather than participation, which means that local authorities are not compelled to incorporate residents but may consult them on issues that they think are necessary to do so.

Kamete (2000b:48) when explaining the political and administrative challenges and arrangements in Zimbabwe concluded that the deterioration of the macro-economic situation since the year 2000 under the management of the former liberation movement (ZANU PF), coupled with a persistent atrocious record of urban governance under a local administration that was entirely made up of representatives from the ruling party, result in the 'informed' urban masses dumping the ruling party en masse and opting for change, a move that was supported strongly by the urban population. Kamete (2000b:48) in addition, believes that the change of faith in ZANU-PF Party and its government exposed the urban populace as enemies of the government and were ultimately labelled as reactionary and not trustworthy as compared to the people living in rural areas.

Chigwata (201:12) further argues that Zimbabwe has always been characterized by the accountability of local governments to the central government rather than to the people. He provided an example were Joseph Msika, a former Minister of Local Government, who indicated that in Zimbabwe, local government entails the division of functions and responsibilities between central and local government and also that the final accountability of local councils remains with the central government, which created local government in the first place. Msika was of the view that local government did not mean the extension of the concept of sovereign self-rule for local authorities. There is confusion in Zimbabwe around the concepts of 'local affairs and locally elected decision makers, on one hand, and the division of functions between central and local government, as well as the transfer of functions inherent in the decentralization debate, on the other. The current local government is not only unintentional but also undemocratic (Chigwata, 201:12).

In support of Chigwata (201:12) and also further elaborating on the local government system in Zimbabwe, Chatiza (2010:28) claims that Zimbabwe local government's dependence on central government, enshrined in the law, is seen as weakening local governance. Chatiza (2010:28) gave reference to De Valk and Wekwete who note that local government conditions in Zimbabwe were such that central government had a lot of powers. In their view the 
conditions open up the possibility that the urban councils can be used by central government institutions for the purpose of implementing their priorities. Urban and Rural District Councils operating environment and relationship to central government form important constraints to exercising decentralised authority, thereby hampering the process of participation.

The discussions have also indicated the challenges associated with adopting democratic governance. The challenges in many countries and in addition, the need to modernise have unleashed varied reforms in these countries. Chakaipa (2010:39) maintains that while acknowledging that the law is not an all conquering instrument on matters of political and social interaction, one cannot deny that some of the problems that local government grapples with in Zimbabwe could be addressed through careful and far reaching legal reforms. There is good rationale in Chakaipa's (2010:39) assertion that law reform in local government needs to be approached with an understanding of the debate on the role of the central state in development.

\section{CONCLUSION}

Devolution as a method of decentralisation adopted in Zimbabwe is important because it gives sub-national institutions some form of autonomy in policy formulation and implementation. Despite adopting decentralisation policy, the Zimbabwean Government has remained dominant of local governments and this is a challenge it has failed to overcome. Lack of efficient and effective institutional structures and political commitment seem to hamper implementation of complete decentralisation policies and reforms. Olowu (2009:1) alleges that Zimbabwe has not been part of the good news as far as the effort to enhance the capacity of local governance is concerned. It is ironic that the resilient institutions of local governance that were inherited at independence have deteriorated over time both in the cities and rural areas. The Zimbabwe Institute (2005:31) concludes that the government has a very clear decentralisation policy, which aims at empowering local authorities and local communities. However, due to a number of reasons, notably, resistance from public servants, lack of political will, limited resources and challenged capacities of sub district structures, it has not been possible to make any significant progress in implementing the decentralisation policy.

To recommend, there is need to encourage political parties to choose candidates for election as councillors who have higher qualifications, the need to amend the current Urban Councils Act and go beyond political demands and demand higher academic and professional qualifications, the need for councils to have a systematic training programme to use as a tool to improve the qualifications of those councillors who enter the system with basic required qualifications, to encourage political parties to training their candidates or representatives so that they are able to articulate the parties agendas when they are engaged in council businesses and distance learning for councillors can be introduced in Zimbabwe like what is happening in Tanzania. Institutions like The Zimbabwe Open University can introduce pilot programmes since they have knowledge and skills on handling distance learners. However, the issue of contracting trainers with hands on experience could still be a problem.

\section{REFERENCES}

Bhagwan, V. and Bhushan, V. 2005. Public Administration. New Delhi: S. Chand and Company LTD.

Cheema, G. S. 2005. Building Democratic Institutions: Governance Reform in Developing Countries. Bloomfield: Kumarian Press Inc.

Chigwata, T. C. 2010. A critical analysis of decentralization in Zimbabwe: focus on the position and role of a Provincial Governor. South Africa, Western Cape. The University of the Western Cape. (Mphil-thesis). 
Zimbabwe. Chombo, I.M.C. 2004. Memorandum By the Minister Of Local Government and National Housing on the Urban Councils (Amendment) Act (Chapter 29:15). Harare: Government Printer. [Laws.]

Chigwata, T. C. 2010. A critical analysis of decentralization in Zimbabwe: focus on the position and role of a Provincial Governor. South Africa, Western Cape. The University of the Western Cape. (Mphil-thesis).

Christensen, T. and Hoen-Esch, T. 2006. Local Politics: A Practical Guide to Governing at the Grassroots. New York: M.E. Sharpe, Inc.

Dhaliwal, S. S. 2004. Good Governance in Local Self-Government. New Delhi: Deep and Deep Publications Pvt. Ltd. Du Toit, D. F. P., Vander Waldt, G., Bayat, M. S. and Cheminais, J. 1998. Public Administration and Management for Effective Governance. Kenwyn: Juta and Company Ltd.

Ferlie, E., Lynn, L. E. and Pollitt, C. 2007. The Oxford Handbook of Public Management. New York: Oxford University Press Inc.

Frederickson, H. G. and Smith, K. B. 2003. The Administration Theory Primer. Boulder: Westview Press.

Frimpong, K. and Jacques, G. (eds). 1999. Corruption, Democracy and Good Governance in Africa: Essays on Accountability and Ethical Behaviour. Gaborone: Lightbooks.

Godwin, P. 2010. The Fear: The Last Days of Robert Mugabe. London: Picadar.

Goel, S. L. 2007. Right to Information and Good Governance. New Delhi: Deep and Deep Publications PVT LTD.

Gompertz, S. 2009. Democracy and the Social Question: Some contribution to a dialogue in Ethiopia. Addis Ababa: Friedrich Ebert Stiftung.

Hall, D. and Hall, I. 2003. Practical Social Research: Project Work in the Community. Hampshire: Palgrave MacMillan Press Ltd.

Heifetz, R. A. and Linsky, M. 2002. Leadership on the Line: Staying Alive through the Boston: Harvard Business School Press.

Dangers of Leading.

Hyden, G., Olowu, O. and Ogendo, H. W. O. 2000. African Perspectives on Governance. Esmara: Africa World Press Inc.

Jonga, W. Looking beyond political qualifications of councillors: A survey of the implications of councillor qualifications to good governance in urban councils of Zimbabwe

Jonga, W. 2012. Good Governance through Staff Development in Zimbabwe Urban Councils: Training of Councillors. Saarbrucken, LAP LAMBERT Academic Publishing

Kjaer, A. M. 2004. Governance. Cambridge: Polity Press.

Larsen, 0.2000. Administration, Ethics and Democracy. Aldershot: Ashgate.

Loopes, C. and Theisohn, T. 2003. Ownership, Leadership and Transformation. New York: Earthscan Publications Ltd.

Magosvongwe G. T., "Challenges For Local Authorities In The New Millenium ( A paper to members of the Urban Councils Association Of Zimbabwe)”, Harare, 1999, (Unpublished report).

Makumbe, J. M. 2009. Zimbabwe; Survival of a Nation. Addis Ababa: Organization for Social Science Research in Eastern and Southern Africa (OSSREA).

Matlosa, K. 1998. Governance in Southern Africa: Training Of Parliamentarians And Councillors (Regional Research Project). Harare: Southern Regional Institute for Policy Studies.

Mawhood, P. 1983. Local Government in the Third World: The Experience of Tropical Africa. Chichester: John Wiley and Sons.

Minogue, M. P. C. and Hulme, D. 2000. Beyond The New Public Management: Changing ideas and practices in governance. Cheltenham: Edward Elgar Publishing Limited.

Momba. J. C. and Kalabula, M. D. 2007. Governance and Public Services Delivery in Zambia. Lusaka: UNZA Press.

Moser, C. A. and Kalton, S. 1980. Survey Methods in Social Investigation. London: Sage Publications.

Olowu, D.and Wunch, J. S. 2004. Local Government in Africa; the Challenges of Democratic Decentralisation.

Boulder: Lynne Rienner Publisher, Inc.

Owens, R. G. 2004. Organizational Behavior in Education: Adaptive Leadership and School Reform. Eighth Edition. 
Boston: Pearson Education, Inc.

Rosenbloom, D. H., Kravchuk, R. S. and Clerkin, R. M. 2009. Public Administration: Undestanding Mnagement, Politics and Law in the Public Sector. Boston: McGraw Hill.

Ruble, B. A., Stren, R.S., Tulchin, J. S. and Varat, D. H. 2000. Urban Governance Around The World. New York: World Bank.

Sachikonye, L. M. 2000. Zimbabwe Human Development Report. Harare: United Nations Development Progamme.

Shaul, R. 2003. Foreword in (Friene, P.): Pedagogy of the Oppressed. London: Sage Publications.

Sharma, K. C.1995. Critical Issues in Local Government Management and Development Related to Central-local Government Relations in Botswana: Lessons of Relevance for Restructuring of Local Government in Postapartheid South Africa. [In Reddy, P.S. (ed), Perspectives on Local Government Management and Development in Africa. Pinetown: Kohler. pp. 50-56.]

Sartori G. 1987. The Theory of Democracy Revisited. Chatham: Chatham House Publishers, Inc.

UCAZ, “Councillors Induction Training Programme 9 September - 3 October 2003”, Harare, 2003, (Unpublished report).

UCAZ, “Councillors Induction Training Programme”, Harare, 2003, (Unpublished report).

UCAZ, “Good Urban Governance”, Harare, 2003, (Unpublished report).

UCAZ, "Induction Training Programme For Councillors: Final Project Completion Report: 20 October - 20 November 2004", Harare, 2004, (Unpublished report).

UCAZ, "Strategic Business Plan 2000 - 2004", Harare, 2003 , (Unpublished report).

Van den Dool, L. 2005. Making Local Government Work; An Introduction to Public Management for Developing Countries and Emerging Economies. Rotterdam: Eburon Delft.

Zimbabwe. Chombo, I.M.C. 2004. Memorandum By the Minister Of Local Government and National Housing on the Urban Councils (Amendment) Act (Chapter 29:15). Harare: Government Printer. [Laws.]

\section{Internet Sites}

Africa, Caribbean and Pacific Local Government Platform. 2005. ACPLGP response to the EC consultation on democratic local governance, decentralisation and territorial development. [Online]. Available: www.acplgp.net/.../ACPLGP_Response\%20to\%20EC\%20Consultatio... [27December 2011].

Boin, A. and Christensen, T. 2008. The Development of Public Institutions: Reconsidering the Role of Leadership. (Online). Available: http://online.sagepub.com [20 September 2011].

Cameron, G. and Dorman, S. 2009: Problems of Nationalism and Democracy in Zimbabwe and Tanzania. [Online]. Available:

http://www.polis.leeds.ac.uk/assets/files/events/democratization-2009/cameron-dorman.pdf - [24 June 2012].

Chakaipa, S. 2010. Local Government Institutions and Elections. [In De Vessr, Steytler and Machingauta (eds), Local government reform in Zimbabwe: A policy dialogue. [Online]. Available:

http://www.ldphs.org.za/publications/publications-by-theme/local-government-in-africa/De\%20Visser$\% 20$ Steytler\%20and\%20Machingauta\%20-

\%20The\%20Future\%20of\%20Local\%20Government\%20in\%20Zimbabwe\%20-\%20A\%20Policy\%20Dialogue.PDF [13 October 2012]. pp 31-68.]

Chatiza, K. 2010. Can Local Government Steer Socio-Economic Transformation in Zimbabwe? Analysing Historical Trends and Gazing into the Future. [In De Vessr, Steytler and Machingauta (eds), Local government reform in Zimbabwe: A policy dialogue. [Online]. Available:

http://www.ldphs.org.za/publications/publications-by-theme/local-government-in-africa/De\%20Visser\%20Steytler\%20and\%20Machingauta\%20- 
\%20The\%20Future\%20of\%20Local\%20Government\%20in\%20Zimbabwe\%20-\%20A\%20Policy\%20Dialogue.PDF [13 October 2012]. pp 1-25.]

Chigwata, T. C. 2010. A critical analysis of decentralization in Zimbabwe: focus on the position and role of a Provincial Governor. [Online]. Available:

www.ldphs.org.za/...government/decentralization-in-zimbabwe/.../im.... [19 June 2012].

Chogugudza, C. 2008. Failure of Democracy in Zimbabwe, a Tragedy for SADC and Beyond. [Online]. Available: www.africaresource.com/index.php?...democracy-in-zimbabwe... [23 June 2012].

Chombo, I. 2010. Speech by the Honourable Minister of Local Government, Rural and Urban Development at an Official Opening of the Policy Dialogue on the Future of Local Government in Zimbabwe held at Holiday Inn, Harare, 3 November 2009. [Online]. Available:

http://www.ldphs.org.za/publications/publications-by-theme/local-government-in-africa/De\%20Visser\%20Steytler\%20and\%20Machingauta\%20\%20The\%20Future\%20of\%20Local\%20Government\%20in\%20Zimbabwe\%20-\%20A\%20Policy\%20Dialogue.PDF [31 November 2012]. pp. ix-xii]

Chombo Threatens Harare City Council. 2012. New Zimbabwe Newspaper. 5. October 12. [Online]. Available: http://www.zimbabwesituation.com/oct14_2012.html\#.UHpJEXJMihE [13 October 2012].

Chou, M. 2011. When Democracies Fail. [Online]. Available: DOI: 10.1111/j.1478-9302.2011.00237.x [2 March 2012].

Ehiobuche, C. and Hui-wen, T. 2012. Towards The Relevance Of Classical Management Theories and Organisation Behaviour. [Online]. Available:

http://asbbs.org/files/ASBBS2012V1/PDF/E/EhiobucheC2.pdf [13 July 2012].

Global Campaign on Urban Governance UN-HABITAT. 2001. Urban Governance Index (UGI). [Online]. Available: www.unhabitat.org/downloads/docs/2232_80907_UGIndex.doc [10 March 2012].

Human Settlements Group. 2009. What role for mayors in good city governance? [Online]. Available: http://pubs.iied.org/pdfs/10579IIED.pdf [7 October 20012].

IFRC. 2011. Zimbabwe: Cholera Outbreak - Jul 2011. [Online].

Available: http://reliefweb.int/disaster/ep-2011-000083-zwe [28 September 2012].

International Institute for Democracy and Electoral Assistance (IDEA). 2004. Democracy at the Local Level in East and Southern Africa: Profiles in Governance. [Online]. Available:

www.idea.int/publications/dll_africa/upload/Full_Report.pdf [23 June 2012].

Institute for Democratic Alternative for Zimbabwe. 2010. Local Governance in Transition: Zimbabwe's Local Authorities during the Inclusive Government. [Online]. Available:

http://www.rti.org/pubs/zimbabwe_local_governance_report.pdf [26 November 2011].

Jonga, W. and Chirisa, I. 2009. Urban Local Governance in The Crucible: Empirical Overtones Of Central Government Meddling In Local Urban Councils Affairs In Zimbabwe. [Online]. Available:

ideas.repec.org/a/rom/terumm/v4y2009i12p166-182.html [13 October 2012].

Kamte, A. 2000b. In Defense of National Soverenity? Urban Governance and Democracy in Zimbabwe. [Online]. Available: www.hsrcpress.ac.za/downloadpdf.php?... [10 October 2012].

Khandakar, Q. E. 2009. UNDP on good governance. [Online]. Available: www.emeraldinsight.com/0306- 8293.htm [15 September 2011].

Kigongo-Bukenya, I. M. N. 2011. Enhancing democracy and good governance: A curriculum proposal for information/knowledge management professionals (IKMPS). [Online]. Available: www.emeraldinsight.com/00242535.htm [9 August 2011].

Machin, D. J. 2012. Political Legitimacy, the Egalitarian Challenge, and Democracy. [Online]. Available: http://0nlinelibrary.wiley.com.oasis.unisa.ac.za/doi/10.1111/j.1468-5930.2012.00556.x/pdf [24 March 2012]. 
Marike Vaa, A.T.I.T. (2001): ASSOCIATIONAL LIFE IN AFRICAN CITIES: Popular Responses to the Urban Crisis in www.cmi.no/.../publication/?952=associational-life-in-african-cities-Accessed 18 February 2012

Machingauta, N.2009. A legal analysis of the appointment of caretakers to act as council in terms of Zimbabwe's section 80 of the Urban Councils' Act. [Online]. Available:

http://etd.uwc.ac.za/usrfiles/modules/etd/docs/etd_gen8Srv25Nme4_5852_1306483047.pdf

[7 October 2012].

Madzivanyika, L. 2011. The impact of weaknesses in the Urban Councils Act on efficient and effective service delivery in urban local councils in Zimbabwe. [Online]. Available: www.mlgi.org.za/...local-government/service-delivery-inurban-local... [13 October 2012].

Makumbe, J. 2009. The impact of democracy in Zimbabwe: assessing political, social and economic developments since the dawn of democracy. [Online]. Available:

www.cps.org.za/cps\%20pdf/RR119.pdf [11 January 2013].

Mapuva, J.2001. Enhancing local governance through local initiatives: Residents' associations in Zimbabwe. [Online]. Available: http://www.academicjournals.org/ajhc/PDF/pdf2011/Feb/Mapuva.pdf [12October 2012].

Marumahoko, S. and Fessha, Y.T. 2011. Fiscal autonomy of urban councils in Zimbabwe: A critical analysis. Available: www.ajol.info/index.php/ldd/article/view/72715 (Accessed 24 May 2012)

Marumahoko, S. 2010. Testing the Boundaries Of Zimbabwe's Fiscal Decentralisation For Urban Councils. [Online]. Available: http://etd.uwc.ac.za/usrfiles/modules/etd/docs/etd_gen8Srv25Nme4_9240_1306474103.pdf

[7 October 2012].

Martin, R and Musandu-Nyamayaro. O. 2004. Long-term Local Government Support Program.

Mid-Term Review (Final Report). [Online]. Available: www.oecd.org/countries/zimbabwe/35823341.pdf [13 October 2012].

Marondera Mayor Arrested. 2012. The Zimbabwean Newspaper. 1. Wednesday, 10 October. [Online]. [Available: http://www.thezimbabwean.co.uk/news/zimbabwe/57524/local-government-government-media-content.html [10 October 2012].

Mason, P. R. 2009. Emerging Problems in Infectious Diseases: Zimbabwe experiences the worst epidemic of cholera in Africa. [Online]. Available:

jidc.org/index.php/journal/article/download/19755746/44 [11 October 2012].

Mehde, V. 2006. Governance. Administrative Science and the Paradoxes of New Public Management. [Online]. Available: http://www.sagepublications.com [5 July 2011].

Mgonja, B. E. S. 2010. Alternative Thinking on Governance: A Critical Analysis of Structures and Uncertainty in Embedding Good Governance at the local Level in Tanzania. Canada, Ottawa. Heritage. University of Alberta. (PhD Thesis. [Online]. Available: https://era.library.ualberta.ca/public/datastream/get/uuid.../DS1 [30 September 2012].

Monatzeder, H. 2004. City of Munich Condemns the Dismissal of Harare Executive Mayor Elias Mudzuri. Zimbabwe in the year 2012. Kubatana.net. April 22. [Online]. Available:

http://www.kubatana.net/html/archive/locgov/040422mun.asp?sector=LOCGOV\&year=2004\&range_start=61 [8 October 2012].

Moreno, C. L. 2005. Decentralisation, Electoral Competition and Local Government Performance in Mexico. U.S.A. Faculty of the Graduate School of the University of Texas at Austin. (PhD - Thesis). [Online]. Available: www.lib.utexas.edu/etd/d/2005/morenoc72203/morenoc72203.pdf [30 September 2012].

Mouritzen,P. E. and Svara, J. 2002. Leadership At The Apex: Politicians and Administrators in Western Local Governments. [Online]. Available:

http://books.google.com.et/books?id=pP6ECFtzH6oC\&printsec=frontcover\&source=gbs_atb\#v=onepage\&q\&f=false [23 September 2011]. 
Moyo, M. 2010. Devolution and its benefits for Zimbabwe in the Zimbabwe. The Independent Thursday, 01 July 2010. (Online]. Available: http://www.theindependent.co.zw/local/27083-devolution-and-its-benefits-for-zim.html [10 June 2011].

Olowu, D. 2009. Decentralization and Local Government in the Zimbabwean Constitution. [Online]. Available: tsime.uz.ac.zw/.../WmltX09sb3d1X0RlY2VudHJhbGl6YXRpb24uZ [29 Septembr 2012].

Ozor, F. U. 2009. Electoral Process, Democracy and Governance in Africa: Search for an Alternative Democratic Model. [Online]. Available: http://www.tandfonline.com/loi/cpsa20 [30 September 2012].

Peter R. M. and Peter, S. 2008. Emerging Problems in Infectious Diseases. [Online]. Available:

jidc.org/index.php/journal/article/download/19755746/44 [28 September 2012].

Phiri, F. (2004) URBAN COUNCILS ASSOCIATION OF ZIMBABWE (UCAZ):

The Role of Local Government Associations:The Zimbabwean Experience, Available: www.lgazambia.org.zm/.../Zimbabwe\%20information\%20for\%20co... Ac 'cessed -20 January 2012

Rambanapasi, C. O. 1992. Development of the Local Government System in Zimbabwe. [Online]. Available: www.tandfonline.com/doi/abs/10.1080/01900699208524771 [23 February 2012].

Residents Storm Council Office. 2012. The Zimbabwean Newspaper. 1. Wednesday, 10 October. [Online]. [Available: http://www.thezimbabwean.co.uk/news/zimbabwe/57524/local-government-government-media-content.html [10 October 2012].

Sachikonye, L. M. Chawatama, S. Mangongera, C. Musekiwa, N. and Ndoro, C. 2007. Consolidating Democratic Governance in Southern Africa:Zimbabwe. [Online]. Available: www.eisa.org.za/PDF/rr30.pdf [10 October 2012].

Saltzstein, A. L., Copus, C., Sonenshein, R. J. and Skelche, C. 2008. Vision of Urban Reform: Comparing English and U.S. Strategies for Improving City Government. [Online]. Available: http://onlinesagepub.com [6 July2011].

Sibanda, T. 2012. Chombo and his deputy row over suspension of Gwanda mayor. [Online]. Available: http://www.zimbabwesituation.org/?p=32523 [28 January 2013].

Tambulsi, R. I. C. 2011. Local government without governance: A New Institutional Perspective of Local Governance Policy Paralysis in Malawi. [Online]. Available: http://www.sagepublications.com [30 July 2011].

Tanyanyiwa Removed From House Arrest. 2012. The Zimbawean Newspaper. 1. Wednesday, 10 October. [Online]. [Available:

http://www.thezimbabwean.co.uk/news/zimbabwe/57524/local-government-government-media-content.html [10 October 2012].

Tewdwr-Jones, M. and McNeill, D. 200.The Politics of City-Region Planning and Governance : Reconciling the National, Regional and Urban in the Competing Voices of Institutional Restructuring. [Online]. Available:

http://www.sagepublications.com [July 2011].

Townsend, J. and Copson, R. W. 2005. Zimbabwe: Current Issues. [Online]. Available:

fpc.state.gov/documents/organization/46401.pdf [24 June 2012].

UN-HABITAT. 2010. African Cities 2010; Governance, Inequality and Urban Land Markerts; Nairobi. [Online]. Available: www.unhabitat.org [10 March 2012].

Wilson, D. 2000.Towards Local Governance: rhetoric and reality. [Online]. Available: http://www.sagepublications.com [5 July 2011].

ZANU PF Resists Skills Audit. 2012. The Zimbawean Newspaper. 1. Wednesday, 10 October. [Online]. [Available:

http://www.thezimbabwean.co.uk/news/zimbabwe/57524/local-government-government-media-content.html [10 October 2012].

ZANU PF's Violent Chipangano Gang Running a 'Parallel Council' in Harare. 2012. The Zimbawean Newspaper. 1. Wednesday, 10 October. [Online]. [Available:

http://www.thezimbabwean.co.uk/news/zimbabwe/57524/local-government-government-media-content.html [10 October 2012].

Zimbabwe Election Support Network. 2008. Post-Election Update 3; April 28 to May 15 2008. [Online]. Available: www.zesn.org.zw/publications/publication_212.doc [9 October 2012].

Zimbabwe Institute. 2005. Local Government: Policy Review. [Online]. Available: 
www.kubatana.net/docs/.../zim_institute_loc_gvt_paper_0506.doc [8 October 2012].

Zimbabwe United Residents Association \& Combined Harare Residents Association. 2003. A policy advocacy paper on amendments to legislation on local government in order to achieve authentic civic participation in urban councils' administration and management for improved local governance and service delivery. [Online]. Available: www.kubatana.net/docs/.../chra_zura_policy_amd_locgov_030331.p... [10 October 2012].

Zimbabwe Women's Resource Centre and Network. 2010. Local Government Policy and 2010 budget analysis. [Online]. Available:

http://www.zwrcn.org.zw/downloads/BUDGET\%20ANALYSIS\%200F\%20THE\%202010\%20LOCAL\%20AUTHORITY \%20BUDGETS\%20AND\%20POLICIES\%20.pdf [13 October 2012].

Zimunya, F. 2004. Training of Mayors: The Experience of Zimbabwe. [Online]. Available:

http://www.lgazambia.org.zm/LGAZ\%20Information/LGAZ\%20Materials/Zimbabwe\%20information\%20for\%20co uncils/Mayoral_System_in_Zimbabwe.pdf [8 October 2012].

Zwart, I. 2009. Deliberative Democracy and Community Storm water Management in Public Administration Today. [Online]. Available: http://www.sagepublications.com [25 March 2012].

Government Documents

Zimbabwe. Chombo, I.M.C. 2004. Memorandum By the Minister Of Local Government and National Housing on the Urban Councils (Amendment) Act (Chapter 29:15). Harare: Government Printer. [Laws.]

Zimbabwe. Ministry of Local Government, Public Works and National Housing. 2004. The Revitalization of Local Authorities. Harare: Government of Zimbabwe. [Unpublished]

Zimbabwe. Ministry of Local Government, Public Works and National Housing. 2004. The State Of Local Government in the Country. Harare: Government of Zimbabwe. [Unpublished]

Zimbabwe. Ministry of Local Government, Public Works and National Housing. 1996. Urban Councils Act Chapter 29:15. Harare: Government of Zimbabwe.

Zimbabwe.2002. Urban Councils Amendment Act. Government Printer. [Laws.]

Journals

Cooter, R. D. and Gilbert, M. I. D. 2010. A Theory of Direct Democracy and the Single Subject Rule. Columbia Law Review, 110 (3) pp. 687-730

Munzwa, K. and Jonga, W. 2009. Urban Development in Zimbabwe: A Human Settlement Perspective. Romania, Theoretical and Empirical Researches in Urban Management Journal (TERUM).

Wekwete, K. 2006. Urban local government finance in Zimbabwe: The case of Harare City Council. Public Administration and Development, 12(1) pp. 97-110

\section{Newspapers}

Brian James suspension Exposes Ugent Need for Local Government Reform. 2012. The Zimbabwean. February 1. pp.1 Conflict of the Minister of Local Government and mayors over the introduction of District Administrators in urban areas. 2003. The Financial Gazette. February 27 - March5. pp. 4

Councillors and mayors under siege from Chombo. 2012. The Zimbabwean. February 24. pp.1

Garbage not collected since August in Chitungwiza. 2005. The Herald. November 22. pp.1

Garbage an eyesore even in the up market suburbs. 2005. The Sunday Mail. November 20-26. pp. M14

Mayor and Councillors in Mutare Urban Council Resign. 2006. The Manica Post. February 3-9. pp.1

Mayor and councillors of Mutare City Council Resign. 2006. The Manica Post. January 6-12. pp. 9

Nyaira, S. and Mhlanga, S. 2012. Diarrhea Outbreaks in Zimbabwe Revive Fears of Another Cholera Epidemic. Voice of America. September, 28. pp.1 